\title{
CHANGES IN THE CONTENT OF MOLECULES OF MIDDLE MASS IN ANIMALS IN CONDITIONS OF SERIOUS INJURY ON THE BACKGROUND OF POISONING BY SALTS OF COPPER AND ZINC
}

\author{
๑O. E. Kopach, G. A. Krytska, O. E. Fedoriv, N. A. Melnyk \\ I. Horbachevsky Ternopil State Medical University
}

SUMMARY. Trauma of various degree of severity is accompanied by severe endotoxicosis, which increases with the injury severity. Excessive ion exchange of copper and zinc also causes an increase in the level of molecules of middle mass.

KEY WORDS: polytrauma; zinc and copper; molecules of middle mass; endogenous intoxication.

Introduction. Injuries in the modern world is one of the leading health problems. Each year about 5 million people in the world and more than 30 thousand people in Ukraine die from their lives as a result of injuries. The most widespread traumatism is among children and persons of working age. Trauma is one of the main causes of mortality of the young and most able-bodied population. Along with this, the territory of Ukraine is exposed to significant influence of adverse environmental factors, among which the leading place is allocated to the salts of heavy metals. If in the industrial regions of Ukraine (central, southern and eastern) in the soil and water dominated cadmium, lead and strontium88, then copper and zinc predominate throughout Ukraine, in particular in non-industrial regions. A clear evidence of this is the data on the excessive accumulation of copper and zinc ions in living organisms inhabiting the reservoirs of the Ternopil region, and exceeding the MMM by copper ions in the drinking water of the city Ternopil in 20 times, and by zinc ions in 3 times, as evidenced by the Environmental Monitoring Program Ternopil region for 2006-2010 years.

The aim of the study - to establish the peculiarities of the development of endogenous intoxication after the simulation of skeletal trauma of varying severity in the presence of excess copper and zinc salts in the body.

Materials and Methods. Experiments were performed on non-linear white male rats weighing 180$200 \mathrm{~g}$. Chronic intoxication with copper and zinc sulfates was carried out according to the method of Zasekin (2001) by daily administration into the stomach through a probe of their solutions in a dose of $5 \mathrm{mg} / \mathrm{kg}^{-1}$ in terms of metal once a day. After 14 days, in conditions of thiopental-sodium anesthesia (40 mg kg-1 of body weight), animals simulated skeletal trauma of varying severity. The control group was animals that simulated skeletal trauma without poisoning heavy metal salts.
After 1,3 and 7 days of the post-traumatic period, the animals were withdrawn from the experiment under conditions of thiopental-sodium anesthesia (60 mg kg-1 - body weight) by total blood flow to the heart. To assess the level of endogenous intoxication in serum, the content of fractions of a molecule of average mass at a wavelength of 250 and $280 \mathrm{~nm}$ was determined.

Results. An important element in the pathogenesis of traumatic illness is the development of endotoxicosis. In the bridge MMM254 in both experimental groups significantly increased to 3 days, which was proportional to the severity of the injury, followed by a decrease of up to 7 days.

Skeletal trauma of various degree of severity was accompanied by pronounced endotoxicosis, which became more severe as the severity of the injury increased. Excessive ion exchange of copper and zinc was accompanied by a greater increase in the level of endotoxicosis. The severity of these moves grew against the background of injuries of moderate and severe degrees. Compared to animals without additional intoxication after an average grade injury, the content of MMM fraction 250 in blood was significantly higher in 1 and 7 days (14.2 and $13.2 \%$, respectively, respectively, $p<0.05)$, and the content in the blood of the MMM fraction 280 - with all terms of observation (on average $15.3 \%$, p<0.05). After severe trauma, the content of both fractions of MSM was significantly greater only after 1 day of the posttraumatic period $(p<0.05)$.

Conclusion. Thus, an injury of varying degrees of severity is accompanied by severe endotoxicosis, which increases with the severity of the injury. At the same time there is a natural increase in the content of MMM of both fractions by the third day with the subsequent decrease to the seventh. Excessive intake of copper ions and zinc also causes an increase in the level of endotoxicosis, which was most noticeable after a trauma of moderate severity at all time of observation and after severe trauma after 1 day of post traumatic period. 
Огляди літератури, оригінальні дослідження, погляд на проблему

\section{LITERATURE}

1. Volotovskaya N. V. Features of the reaction of peroxide lipid oxidation, antioxidant defense, endogenous intoxication and cytolysis under the influence of trauma of varying severity / N. V. Volotovskaya, A. A Hudyma // Achievements of Clinical and Experimental Medicine. 2012. - No. 1 (16). - P. 29-33.

2. Elsky V. N. Modeling of Craniocerebral Injury / V. N. Elsky, S. V. Zyablytsev. - Donetsk : Publishing house «New World», 2008. - 140 p.

3. Kopach O. E. Effect of copper and zinc salts on dy- namics of cytolytic process in mechanical trauma of varying severity / O. E. Kopach, A. A. Gudyma // Journal of Health Sciences. - 2013. - No. 3 (10). - P. 225-232.

4. Kopach O. E. Influence of chronic intoxication with copper and zinc salts on the level of endogenous intoxication in the dynamics of mechanical trauma of varying severity / O. E. Kopach // Bulletin of Scientific Researches.

5. World report is road traffic injury prevention / M. Peden, R. Scurfield, D. Sleet [et al.]. - Geneva, Switzerland : World Health Organization, 2004.

\section{REFERENCES}

1. Volotovskaya, N.V., Hudyma, A.A. (2012). Features of the reaction of peroxide lipid oxidation, antioxidant defense, endogenous intoxication and cytolysis under the influence of trauma of varying severity. Achievements of Clinical and Experimental Medicine, 1 (16), 29-33.

2. Elsky, V.N., Zyablytsev, S.V. (2008). Modeling of Craniocerebral Injury. Donetsk: Publishing house «New World», 140.

3. Kopach, O.E., Hudyma, A.A. (2013). Effect of copper and zinc salts on dynamics of cytolytic process in

mechanical trauma of varying severity. Journal of Health Sciences, 3 (10), 225-232.

4. Kopach, O.E. (2014). Influence of chronic intoxication with copper and zinc salts on the level of endogenous intoxication in the dynamics of mechanical trauma of varying severity. Bulletin of Scientific Researches, 1, 89-91.

5. Peden, M., Scurfield, R., \& Sleet, D. (2004). World report is road traffic injury prevention. Geneva, Switzerland: World Health Organization.

\section{ЗМІНИ ВМІСТУ МОЛЕКУЛ СЕРЕДНЬОЇ МАСИ У ТВАРИН В УМОВАХ ТЯЖКОЇ ТРАВМИ НА ТЛІ ОТРУЄННЯ СОЛЯМИ МІДІ ТА ЦИНКУ

\author{
๑о. Є. Копач, Г. А. Крицька, О. Є. Федорів, Н. А. Мельник
}

ДВНЗ «Тернопільський державний медичний університет імені І. Я. Горбачевського МОЗ України»

РЕЗЮМЕ. Травма різного ступеня тяжкості супроводжується вираженим ендотоксикозом, який із зростанням

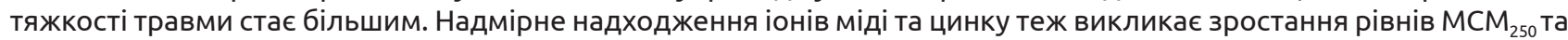
$\mathrm{MCM}_{280}$.

КЛючовІ СловА: політравма; цинк і мідь; молекули середньої маси; ендогенна інтоксикація.

\section{ИЗМЕНЕНИЕ СОДЕРЖАНИЯ МОЛЕКУЛ СРЕДНЕЙ МАССЫ У ЖИВОТНЫХ В УСЛОВИЯХ ТЯЖЕЛОЙ ТРАВМЫ НА ФОНЕ ОТРАВЛЕНИЯ СОЛЯМИ МЕДИ И ЦИНКА}

๑А. Е. Копач, Г. А. Крицкая, О. Е. Федоров, Н. А. Мельник

ГВУз «Тернопольский государственный медицинский университет имени И. Я. Горбачевского МОЗ Украины»

РЕзЮМЕ. Травма различной степени тяжести сопровождается выраженным эндотоксикозом, который с ростом тяжести травмы становится больше. Избыточное поступление ионов меди и цинка тоже вызывает рост уровней $\mathrm{MCM}_{250}$ та $\mathrm{MCM}_{280}$.

КЛЮчЕВЫЕ СЛОВА: политравма; цинк и медь; молекулы средней массы; эндогенная интоксикация. 